Editorial

\title{
Towards Equitable and Sustainable Urban Space: Introduction to Special Issue on "Urban Land and Sustainable Development"
}

\author{
Yehua Dennis Wei ${ }^{1,2}$ \\ 1 Department of Geography, University of Utah, Salt Lake City, UT 84112, USA; wei@geog.utah.edu; \\ Tel.: +86-801-585-0545; Fax: +86-801-585-8218 \\ 2 Department of Land Management, Zhejiang University, Hangzhou 310029, China
}

Academic Editor: Marc A. Rosen

Received: 5 August 2016; Accepted: 9 August 2016; Published: 15 August 2016

\begin{abstract}
The unprecedented wave of global urbanization has exerted increased pressure on urban land and made land-use sustainability an urgent concern. This Special Issue examines patterns, structures, and dynamics of urban land use from the economic, social, and, to a lesser extent, environmental standpoints, in light of the goal of equitable and sustainable development. This introduction discusses the background and design of the Special Issue and highlights the contribution of the selected papers.
\end{abstract}

Keywords: urbanization; urban expansion; urban sprawl; spatial inequality; sustainable development

\section{Introduction}

According to "World Urbanization Prospects" [1], urbanization could add another 2.5 billion people to the global urban population by 2050, with close to 90 percent of the increase concentrated in Asia and Africa. The largest urban growth will take place in India and China. This unprecedented increase in urban population not only poses the challenges of providing jobs, housing, and infrastructure, but also exerts an increased pressure on urban land and makes sustainability a matter of overriding concern.

Sustainability is a broad topic with multiple dimensions, including economic development, health, energy, land use, water consumption, and air pollution, among others. A key component of sustainable development is equity. The recent financial crisis exacerbated income inequality in most countries, although it has had an uneven impact on cities, regions and people. Social and environmental disparities have also been intensified in many countries. Consequently, equity has become a top sustainable development goal of the UN's post-2015 development agenda. Indeed, equality and sustainability are fundamental issues for human society and major concerns of governments worldwide [2,3].

Given the importance of these issues, there are relatively limited studies that explore the global characteristics and mechanisms of urban land change and their consequences in regard to equitable and sustainable development. Land is a vital yet limited resource, and how to cater the needs of the growing urban population and achieve an economically efficient, socially equitable, and environmentally sustainable society are challenging issues. A key tenet is promoting equitable and sustainable land development and mitigating land use conflicts [4]. We need more studies to examine the processes, mechanisms, and effects of urban land use change globally and comparatively. We also need more efforts to better understand the myriad interconnections between urban land use and sustainable development.

This Special Issue examines patterns, structures, and dynamics of urban land use and their implications for equitable and sustainable development from multiple perspectives (inter alia, 
economic, social, and environmental). We examine urban land use and, more broadly, urban space in the contexts of urbanization, institutional change, and governance, as well as the general socio-economic context. During the review process, a high percentage of the manuscripts submitted were rejected, and what remaining all went through 2-3 rounds of review and revision. Papers selected for this Special Issue therefore have been subject to a rigorous peer review procedure with the aim of achieving high quality research and wider dissemination of research results.

\section{Research Background and Progress}

Urban land has been a subject of inquiry for decades. Earlier studies of urban land mainly focused on spatial patterns and internal structure of urban land use, which could be roughly divided into two groups: evolution of different types of urban land use and description of urban land use structure. While land use studies rely on land use data, studies of urban structure look at broader patterns, such as industrial location and population distribution.

Studies of the evolution of urban spatial structure, i.e., the patterns of land use in urban areas and the distribution of different functional zones in the city, were closely associated with the process of industrialization and advances in transportation and communication [5]. Major theoretical contributions of this sort were made by German location theorists and the Chicago School, including the development of traditional models of urban spatial structure, such as the concentric zone model, the sector model, and the multiple nuclei model.

The post-World War II era from the 1950s to the 1960s witnessed the rise of neoclassical economics in social sciences, including the use of factorial ecology in urban social analysis and the examination of urban land value and its linkage with urban form by means of the bid-rent theory [6]. Mounting social problems and the limitations of neoclassical economics prompted the development of alternative thinking in the 1970s and the 1980s, including neo-Marxist urban theories, behavioral approaches and Third World perspectives. Meanwhile, the neoclassical perspective rebounded with the "quantitative revolution", which provided new methods of analyzing urban land use and spatial structure. In this regard, point pattern analysis and fractal dimension were used in the 1980s and the 1990s to quantitatively define urban land use and spatial structure.

With the intensification of globalization and urbanization in the late 1980s, scholars turned their attention to patterns and dynamics of urban expansion firstly in developed countries, followed by studies in the developing countries [7]. Rapid urban transformation prompted a new wave of theorization, which was led by the "Los Angeles School" in the 1980s and 1990s [8]. Post-World War II suburbanization and the resulting urban sprawl in the United States became key topics of academic inquiry. Such studies are often linked to studies of urban form and spatial structure of cities. Scholars have also sought to describe the regularities of urban space based on the spatial concentration of modern human activities, such as traffic flow, imbalance of housing and jobs, mobile communication frequency, and even Wi-Fi access.

GIS and remote sensing have greatly aided empirical studies of land use, especially as regards urban land expansion, sprawl, and land use change. We now have more accurate data on patterns of global urban expansion and sprawl, not just in the West but also in large developing countries undergoing rapid urbanization such as China and India $[9,10]$. In addition, various modeling approaches such as agent-based modeling, geographically weighted regression (GWR), spatial regressions and spatial regime models have been applied to the analysis of the underlying determinants of rural-urban land conversion. Results suggest that multiple natural and socio-economic factors, such as access to central business districts (CBDs), transportation improvement, development of mega-projects and industrial districts, and availability of land in suburban areas, are the primary determining factors of urban land expansion [11-14].

Scholars continue to try to understand the process of urban land expansion and sprawl. Following the notions of Asian development states, scholars have analyzed the role of the Chinese government and growth coalitions in urbanization, land development and urban expansion [15-17]. 
It is argued that even urban sprawl in the United States has been supported by federal housing and transportation policies. Scholars have also investigated issues of power and motivations [18-20].

Urban expansion in developing countries has also been viewed as a process closely linked to the globalization of capital and flow of FDI to developing countries. Adopting the concept of teleconnection, Seto et al. [21] linked global urban land use change to globalization, which broadened the conventional land-use science focus on local factors. Wei and his associates have attempted to apply the notion of China's triple transition of globalization, decentralization and marketization to the understanding of rapid urban expansion in China [22,23].

Great attention has been paid to the interactive effects among urban land use, human society and the physical environment. A rich body of literature has examined the cost of urban expansion and sprawl in developed countries, which tend to see more costs than benefits. Scholars have also linked a variety of urban problems to urban expansion and sprawl, such as spatial inequality in general, residential segregation, job-housing imbalance, spatial mismatch, and food deserts. In addition, a recent study has found that urban sprawl holds down upward intergenerational mobility [24]. As regards health, adults living in sprawling metropolitan areas tend to walk less, are more obese, and suffer more from high blood pressure [25]. Urban sprawl may provide more housing choices for residents, but more centralized metropolitan areas actually exhibit lower median home prices and lower proportions of homes in upper-end price categories than sprawling regions [26].

Scholars have linked urban expansion and sprawl with sustainability and transportation issues [27]. "Compact city" and transit-oriented development have been promoted for more effective use of public transportation systems [28]. Sprawl is associated with significantly higher fatal crash rates [29], and higher costs of infrastructure [30]. Environmentally, air pollution tends to a more serious problem with urban sprawl. Large sprawling metropolitan regions experience a greater number of excessive ozone concentrations than more spatially compact ones [31], and the geographical scope of the urban heat-island effect also tends to expand [32].

As Ewing et al. [24] summarize, there have been reported benefits of urban sprawl as well. Suburban sprawl is seen as a natural manifestation of the American Dream of a big house in the suburbs and tends to improve resident's quality of life in some respects [33,34]. While urban sprawl has decentralized jobs, the rise of suburban population and employment can lead to shorter average commute time [35].

Overall, a large body of literature has dealt with urban land and space due to the consequences of intensified human activity upon resources, social relations and the natural environment [4]. However, more studies are still needed to provide comprehensive analysis of patterns, mechanisms, and effects of urban land use change. In the context of globalization and institutional change, more studies are also needed to better understand urbanization and urban expansion, and their influences on urban space, structure and environment.

\section{Research Themes, Topics and Questions}

While there is a rich literature on urban land and impacts of urban sprawl, there is little understanding of how urban land and space may affect so called "topical outcomes" such as life expectancy, spatial inequality, housing, and transportation costs. Rising income inequality, and associated lack of upward mobility, have become two of the most important issues of our time [2,36]. While income inequality often makes headlines of news, urban spatial inequality remains less studied and upward mobility is barely on the radar of geographers and planners [3]. The effects of urban space on rising inequality, which are of urgent concern both for developed and developing countries, is largely missing in the literature.

While the discourses on sustainability emphasize overall interactions among the three pillars of sustainable development-society, economy, and environment-most of the research has been focused on preserving the ecological capital against economic growth and development or vice versa. There is little research on the intertwinement of the economic, social (e.g., health, inclusion), and 
environmental dimensions of sustainable development, which constitutes the essence of sustainability of urban societies.

This Special Issue examines patterns, structure, and dynamics of urban land use change from multiple perspectives, in various contexts and with multiple foci (economic, social, political, developmental, environmental etc.). The research articles examine urban land development and sustainability arising from globalization, urbanization and institutional change. We have identified the following key areas as relevant to the theme of this Special Issue:

- Patterns and trajectories of urban land use change

- Drivers of urban land expansion/sprawl

- Urban land use, metropolitan development and global change

- Urban land and economic/social/environmental sustainability

- Sustainable land use policies and practices

We have also proposed the following potential topics for study:

- Urban land use: patterns, restructuring, efficiency and equity

- Urban land expansion/sprawl: directions, structures, dynamics/trajectories, drivers

- Land development: globalization, development zones, mega projects, global(izing) cities, and "land grabs", space/place/geography as agents

- Urban land use policy and governance; role of institutions

- Global-local: effects of globalization, land development and global change

- Urban land and economic/social/environmental equity and sustainability

- Sustainable land use and urban development policies and practices

- Methodology: ESDA, spatial regression, GWR, multi-agent based modeling, spatiotemporal dynamics, joint decision-making scenario analysis, etc.

We have further raised the following questions to address in research:

- What are the nature, structure and trajectory of urban land expansion, sprawl and development in different contexts?

- What are the underlying mechanisms and the main drivers of urban land use change? What is sustainable urban land use in the context of increasing global urban population and climate change and how can it be achieved?

- What implications do the practices of urban land use have on sustainable development at the local, regional, and global scales?

- What are the governance and political processes?

- How to measure the roles of geography, contexts and institutions?

- How are urban land use and sustainability displayed in terms of convergence/divergence, dimension, scale and time?

- How to use developments in GIS and big data to advance our knowledge?

- What are the theoretical and policy implications of the research?

\section{Content and Contribution of the Special Issue}

This Special Issue includes 14 articles, with various research emphases, methodologies and study areas, reflecting the inter-disciplinarily that characterizes urban and land use studies. These papers can provide us insights into the underlying structure and mechanisms of urban land expansion, and open new frontiers on the effects of urban land development on both the natural and human environments. For the purpose of this editorial introduction, the papers can be grouped under the following three aspects: (1) investigating urban land space by employing varied measurements and methods; (2) addressing the structure and mechanisms of urban land expansion and urbanization; (3) exploring ecological, environmental and socioeconomic effects and footprints of urban land development. 


\subsection{Multi-Scalar Patterns and Mechanisms of Urban Land Expansion}

This group includes six papers, ranging from the global to the national and local scales, all with a focus on China. At the global scale, Liu et al. test the four prominent hypotheses about patterns of urbanization for sixteen world cities over the period from 1800 to 2000 [37]. The result shows that all these cities have shared three common patterns in urban landscape change: urban landscapes become compositionally more diverse, structurally more fragmented and geometrically more complex as urbanization progresses. Moreover, the dominant patterns of urban land expansion are mainly shifting among infilling, edge expanding and leapfrogging.

On the national scale, using panel data of 253 prefecture-level Chinese cities from 1999 to 2012 [38], Fan et al. investigate the mediating effect of public infrastructure between urban land development and economic growth, and find that public infrastructure is a partial but significant mediator. Land development has a positive impact on public infrastructure, which further facilitates urban economic development.

The next three articles examine urban land use in specific cities and regions in China, including the Yangtze River Delta (YRD), Shenzhen and Beijing. In the first, Gao et al. apply the economic transition framework of globalization, marketization, decentralization, and urbanization, and find that urban land expansion in the YRD is mainly characterized by the growth of residential and industrial land [39]. They identify six factors-foreign direct investment, labor force, government competition, institutions, population, and job-housing relations-as the major underlying driving forces underlying urban expansion.

Qian et al. describe and evaluate the evolution of urban land expansion and land use policy in Shenzhen, China since 2005 [40]. They find that the current mandatory, top-down mode of control, which relies on the central government, has very limited effects on controlling urban expansion. However, such policies as governmental self-restraint, governmental identity change, and policy innovation are effective on guiding China's urbanization.

Relying on CLUE-S model, Markov model and remote sensing data, Han et al. develop two scenarios of urban land expansion (development scenario and protection scenario) to explore the characteristics of land use change and to simulate the future land use demand in Beijing [41]. They find that the conversion from cultivated land to built-up land is still the primary feature of land use change in Beijing. Based on their prediction, the conversion of cultivated land to built-up land in mountainous areas of Beijing will be more prevalent by 2020, and the city will still face a great need for ecological and cultivated-land protection.

Moving to the local scale, Zhao et al. explore the formation process and the determinants of gated informal housing communities in Beijing [42]. This study addresses the role of villages and townships in informal land development and their conflicts with state regulation, and suggests that decentralization and marketization have significantly changed the roles of different levels of government. Instead of following the goals settled by upper-level administration, a township government seems to be more concerned about the quality of local livelihood.

In addition to Chinese cities, this Special Issue also includes a study focusing on urban land use change in Western cities. Monterio and Tavares analyze the spatial and temporal dynamics of land use change in a medium/small city in Portugal between 1958 and 2011, with an explicit emphasis of the planning framework [43]. They find that urban spatial structure changes in Viseu were mainly characterized by a decrease in annual crops and contraction of arable land, as well as an increase of the continuous and discontinuous urban fabric.

\subsection{New Dimensions of Urban Land Use and Urban Space}

The second group of articles focuses on new dimensions of urban land use and urban space, and how space changes in global/globalizing cities. Based on enterprise registered data in 2010, Huang et al. investigate the employment density distribution as an indicator of urban spatial structure change in Beijing [44]. Their result shows that spatial structure of Beijing is still characterized 
by mono-centric development. To evaluate the process of polycentric development, they identify five sub-centers of Beijing, most of which are located in suburban areas.

Wang et al. examine Shanghai's adoption of wireless technologies in urban and infrastructure development and the spatial distribution of public Wi-Fi access in Shanghai [45]. By mapping both government-sponsored hotspots through the "i-Shanghai" project and the hotspots established by China Mobile Communications Corporation (CMCC), they find that Shanghai's telecommunication providers have been proactive in arranging WLAN hotspots (a proxy of public Wi-Fi or wireless access). Moreover, for the old neighborhoods in the city center and remote sub-districts, the public Wi-Fi infrastructure development of both government and CMCC facilities is still relatively backward. The authors further address the policies in terms of how to promote Shanghai as a more sustainable wireless city.

\subsection{Effects of Urban Land Use Change}

The six papers in the third group deal with how urban land development affects environmental and socioeconomic structures at both the national and city scales. At the national scale, Guo et al. analyze the panel data of 577 recorded disasters in 30 provinces of China from 1985-2011 to identify their links with economic growth [46]. Based on an integrated indicator system with entropy weighting, they find that human capital can turn meteorological hazards into economic growth, while geological disasters cannot trigger local economic growth.

Zhang et al. test how urban rail transit affects housing prices in China [47]. Relying on panel data of 35 Chinese cities from 2002 to 2013, and by controlling other determinants, such as GDP per capita, land price, investment in real estate and population density, they find that a $1 \%$ increase in rail transit mileage will advance housing price by $0.027 \%$. Moreover, they point out that the new rail transit lines have increasingly positive influences on housing price of China.

Yang et al. find that there is a linkage in Chengdu, China between residential land use change and the massive migration and relocation of employees in government departments (EGD), on the one hand, and displacement of urban households by demolition (UDDH), on the other [48]. By tracking the employees hired by state government departments and related branches, they compare residential relocations of EGD and UDDH groups and find that most of the UDDH have migrated from urban centers to fringes, while a large number of EGD still agglomerate close to urban centers. Government interventions differentiate residential relocations of EGD and UDDH, and market mechanisms reinforce this relocation process.

Besides the research focused on China, two studies focus on cities in the United States: Salt Lake City and Seattle. Relying on Utah Household Travel Survey data, Wei et al. analyze the linkages between physical activity (PA), neighborhood land use, accessibility to transportation, and socio-demographic status in Salt Lake County, Utah [49]. By using four-component walkability indices at various geographic scales, they find that PA is associated with neighborhood land use and social demographic status, including the compact design of the neighborhood. Specifically, the current neighborhood design in Salt Lake County only supports people's 20-min walk.

Abel et al.'s paper analyzes the intersections of urban industrial and nonindustrial land use planning, gentrification, and environmental injustice in Seattle, WA [50]. Based on geographic cluster analysis and longitudinal air toxic emission comparisons, the authors quantitatively investigate socioeconomic changes in Seattle Census block-groups between 1990, 2000, and 2009. They find that there is a growing tension between industrial and non-industrial land use, and that Seattle's pattern of development is highly stratified by occupation, income and property values.

\section{Conclusions}

This Special Issue provides comprehensive studies of urban land use change and its implications for equitable and sustainable development. We have drawn papers from both developed and developing countries, with a focus on China due to the rapid rate of urbanization and change there. 
We hope that this Special Issue will contribute to the understanding of urban land use patterns and processes, and their implications for sustainable development. The Special Issue has examined patterns and processes of urban land expansion and sprawl, especially in terms of the conversion of rural land to urban use. It also studies new dimensions of urban space, especially social media. Such studies on the effects of urban land use change are particularly valuable, and more efforts are still needed to advance our knowledge.

Globalization and urbanization are continuous processes, and we understand that many questions have not been fully addressed by papers in this special issue. The papers included could not represent many countries in the developing world, despite our efforts trying to broaden the geographical scope of research. The large number of papers on China is evidence of rising scholarship and the rapid advance of science and education in China. We feel the social consequences of urban expansion and sprawl remain under-investigated, and consequently, we have proposed a special issue on urban expansion, sprawl and inequality in Landscape and Urban Planning. We are looking forward to coordinate more efforts to better understand the processes and consequences of urbanization and urban land use change.

Acknowledgments: I would like to acknowledge the constructive comments of Robert Argenbright, research assistance of Han Li and Komali Yenneti, and the funding of the Ford foundation (0155-0883) and the National Natural Science Foundation of China (41329001). I would also like to express my gratitude to the authors, reviewers and the MDPI team.

Conflicts of Interest: The authors declare no conflict of interest.

\section{References}

1. United Nations. World Urbanization Prospects: The 2014 Revision; United Nations: New York, NY, USA, 2014.

2. Stiglitz, J.E. The Price of Inequality: How Today's Divided Society Endangers Our Future; W.W. Norton \& Company Publishing: New York, NY, USA, 2012.

3. Wei, Y.H.D. Spatiality of regional inequality. Appl. Geogr. 2015, 61, 1-10. [CrossRef]

4. Wei, Y.H.D.; Ye, X. Urbanization, urban land expansion and environmental change in China. Stoch. Environ. Res. Risk Assess. 2014, 28, 757-765. [CrossRef]

5. Anas, A.; Arnott, R.; Small, K. Urban spatial structure. J. Econ. Lit. 1998, 36, 1426-1464.

6. Alonso, W. Location and Land Use; Harvard University Press: Cambridge, MA, USA, 1964.

7. Turner, B.L.; Lambin, E.F.; Reenberg, A. The emergence of land change science for global environmental change and sustainability. Proc. Natl. Acad. Sci. USA 2007, 104, 20666-20671. [CrossRef] [PubMed]

8. Dear, M. Los Angeles and the Chicago school: Invitation to a debate. City Community 2002, 1, 5-32. [CrossRef]

9. Deng, X.; Huang, J.; Rozelle, S.; Uchida, E. Cultivated land conversion and potential agricultural productivity in China. Land Use Policy 2006, 23, 372-384. [CrossRef]

10. Mertes, C.M.; Schneider, A.; Sulla-Menashe, D.; Tatem, A.J.; Tan, B. Detecting change in urban areas at continental scales with MODIS data. Remote Sens. Environ. 2015, 158, 331-347. [CrossRef]

11. Seto, K.C.; Kaufman, R.K. Modeling the drivers of urban land use change in the Pearl River Delta, China. Land Econ. 2003, 79, 106-121. [CrossRef]

12. Luo, J.; Wei, Y.H.D. Modeling spatial variations of urban growth patterns in Chinese cities: The case of Nanjing. Landsc. Urban Plan. 2009, 91, 51-64. [CrossRef]

13. Schneider, A.; Mertes, C.M. Expansion and growth in Chinese cities, 1978-2010. Environ. Res. Lett. 2014, 9, 024008. [CrossRef]

14. Li, H.; Wei, Y.H.D.; Liao, F.H.F.; Huang, Z. Administrative hierarchy and urban land expansion in transitional China. Appl. Geogr. 2015, 56, 177-186. [CrossRef]

15. Wei, Y.H.D. Restructuring for growth in urban China: Transitional institutions, urban development, and spatial transformation. Habitat Int. 2012, 36, 396-405. [CrossRef]

16. Liu, T.; Lin, G.C.S. New geography of land commodification in Chinese cities. Appl. Geogr. 2014, 51, 118-130. [CrossRef]

17. Wei, Y.H.D. Zone fever, project fever: Development policy, economic transition, and urban expansion in China. Geogr. Rev. 2015, 105, 156-177. [CrossRef] 
18. Healey, P.; Barrett, S.M. Structure and agency in land and property development processes: Some ideas for research. Urban Stud. 1990, 27, 89-103. [CrossRef]

19. Gore, T.; Nicholson, D. Models of the land-development process: A critical review. Environ. Plan. A 1991, 23, 705-730. [CrossRef]

20. Ganderton, P. Modeling the land conversation process: A realist perspective. Environ. Plan. A 1994, 26, 803-819. [CrossRef]

21. Seto, K.C.; Reenberg, A.; Boone, C.; Fragkias, M.; Haase, D.; Langanke, T.; Marcotullio, P.; Munroe, D.K.; Olah, B.; Simon, D. Urban land teleconnections and sustainability. Proc. Natl. Acad. Sci. USA 2012, 109, 7687-7692. [CrossRef] [PubMed]

22. Gao, J.; Wei, Y.H.D.; Chen, W.; Chen, J. Economic transition and urban land expansion in Provincial China. Habitat Int. 2014, 44, 461-473. [CrossRef]

23. Huang, Z.; Wei, Y.H.D.; He, C.; Li, H. Urban land expansion under economic transition in China. Habitat Int. 2015, 47, 69-82. [CrossRef]

24. Ewing, R.; Hamidi, S.; Grace, J.B.; Wei, Y.H.D. Does urban sprawl hold down upward mobility? Landsc. Urban Plan 2016, 148, 80-88. [CrossRef]

25. Ewing, R.; Meakins, G.; Hamidi, S.; Nelson, A.C. Relationship between urban sprawl and physical activity, obesity, and morbidity-Update and refinement. Health Place 2014, 26, 118-126. [CrossRef] [PubMed]

26. Wassmer, R.W.; Baass, M.C. Does a more centralized urban form raise housing prices? J. Policy Anal. Manag. 2006, 25, 439-462. [CrossRef]

27. Ewing, R.; Cervero, R. Travel and the built environment: A synthesis. Transp. Res. Rec. 2001, 1780, 87-114. [CrossRef]

28. Cervero, R. Built environments and mode choice: Toward a normative framework. Transp. Res. D 2002, 7, 265-284. [CrossRef]

29. Ewing, R.; Schieber, R.A.; Zegeer, C.V. Urban sprawl as a risk factor in motor vehicle occupant and pedestrian fatalities. Am. J. Public Health 2003, 93, 1541-1545. [CrossRef] [PubMed]

30. Lietske, S.N. Determining the relationship between urban form and the costs of public services. Environ. Plan. B 2012, 39, 155-173. [CrossRef]

31. Stone, B., Jr. Urban sprawl and air quality in large US cities. J. Environ. Manag. 2007, 86, 688-698. [CrossRef] [PubMed]

32. Yue, W.Z.; Fan, P.L.; Wei, Y.H.D.; Qi, J.G. Economic development, urban expansion, and sustainable development in Shanghai. Stoch. Environ. Res. Risk Assess. 2014, 28, 783-799. [CrossRef]

33. Bruegmann, R. Sprawl: A Compact History; University of Chicago Press: Chicago, IL, USA, 2006.

34. Brueckner, J.K.; Largey, A.G. Social interaction and urban sprawl. J. Urban Econ. 2008, 64, 18-34. [CrossRef]

35. Gordon, P.; Lee, B. Spatial Structure and Travel Trends in Commuting and Non-Commuting Travel in US Metropolitan Areas in International Handbook on Transport and Development; Edward Elgar: Cheltenham, UK, 2013.

36. Piketty, T. Capital in the Twenty-First Century; Harvard University Press: Cambridge, MA, USA, 2014.

37. Liu, Z.; He, C.; Wu, J. General spatiotemporal patterns of urbanization: An examination of 16 world cities. Sustainability 2016, 8, 41. [CrossRef]

38. Fan, X.; Zheng, D.; Shi, M. How does land development promote China's urban economic growth? The mediating effect of public infrastructure. Sustainability 2016, 8, 279. [CrossRef]

39. Gao, J.; Wei, Y.H.D.; Chen, W.; Yenneti, K. Urban land expansion and structural change in the Yangtze River Delta, China. Sustainability 2015, 7, 10281-10370. [CrossRef]

40. Qian, J.; Peng, Y.; Luo, C.; Wu, C.; Du, Q. Urban land expansion and sustainable land use policy in Shenzhen: A case study of China's rapid urbanization. Sustainability 2016, 8, 16. [CrossRef]

41. Han, H.; Yang, C.; Song, J. Scenario simulation and the prediction of land use and land cover change in Beijing, China. Sustainability 2015, 7, 4260-4279. [CrossRef]

42. Zhao, P.; Zhang, M. The role of villages and townships in informal land development in China: An investigation on the city fringe of Beijing. Sustainability 2016, 8, 255. [CrossRef]

43. Monteiro, M.; Tavares, A.O. What is the influence of the planning framework on the land use change trajectories? Photointerpretation analysis in the 1958-2011 period for a medium/small sized city. Sustainability 2015, 7, 11727-11755. [CrossRef] 
44. Huang, D.; Liu, Z.; Zhao, X. Monocentric or polycentric? The urban spatial structure of employment in Beijing. Sustainability 2015, 7, 11632-11656. [CrossRef]

45. Wang, M.; Liao, F.H.F.; Lin, J.; Huang, L.; Gu, C.; Wei, Y.H.D. The making of a sustainable wireless city? Mapping public Wi-Fi access in Shanghai. Sustainability 2016, 8, 111. [CrossRef]

46. Guo, J.; Liu, H.; Wu, X.; Gu, J.; Song, S.; Tang, Y. Natural disasters, economic growth and sustainable development in China: An empirical study using provincial panel data. Sustainability 2015, 7, 16783-16800. [CrossRef]

47. Zhang, X.; Liu, X.; Hang, J.; Yao, D.; Shi, G. Do urban rail transit facilities affect housing prices? Evidence from China. Sustainability 2016, 8, 380. [CrossRef]

48. Yang, Y.; Zhang, D.; Meng, Q.; McCarn, C. Urban residential land use reconstruction under dual-track mechanism of market socialism in China: A case study of Chengdu. Sustainability 2015, 7, 16849-16865. [CrossRef]

49. Wei, Y.H.D.; Xiao, W.; Wen, M.; Wei, R. Walkability, land use and physical activity. Sustainability 2016, 8, 65. [CrossRef]

50. Abel, T.D.; White, J.; Clauson, S. Risky business: Sustainability and industrial land use across Seattle's gentrifying riskscape. Sustainability 2015, 7, 15718-15753. [CrossRef]

(C) 2016 by the author; licensee MDPI, Basel, Switzerland. This article is an open access article distributed under the terms and conditions of the Creative Commons Attribution (CC-BY) license (http://creativecommons.org/licenses/by/4.0/). 